Article

\title{
An Exploration of the Relationships between Nostalgia, Involvement, and Behavioral Intention in Diaspora Tourism
}

\author{
Yanfang Zeng ${ }^{1,2}$ and Rui $\mathrm{Xu}^{3, *}$ \\ 1 College of Tourism, Fujian Normal University, Fuzhou 350117, China; yanfang@fjnu.edu.cn \\ 2 The Higher Educational Key Laboratory for Smart Tourism of Fujian Province, Fuzhou 350117, China \\ 3 School of Computer Science and Mathematics, Fujian University of Technology, Fuzhou 350118, China \\ * Correspondence: xurui@fjut.edu.cn
}

check for

updates

Citation: Zeng, Y.; Xu, R. An Exploration of the Relationships between Nostalgia, Involvement, and Behavioral Intention in Diaspora Tourism. Sustainability 2021, 13, 12273. https: / / doi.org/10.3390/ su132112273

Academic Editor: Kyle

Maurice Woosnam

Received: 29 September 2021

Accepted: 29 October 2021

Published: 6 November 2021

Publisher's Note: MDPI stays neutral with regard to jurisdictional claims in published maps and institutional affiliations.

Copyright: (C) 2021 by the authors. Licensee MDPI, Basel, Switzerland. This article is an open access article distributed under the terms and conditions of the Creative Commons Attribution (CC BY) license (https:/ / creativecommons.org/licenses/by/ $4.0 /)$.

\begin{abstract}
Diaspora tourism has become a significant market niche under globalization, but diaspora tourism to China has been less studied. This paper explores the relationships between nostalgia, involvement, and behavioral intention in diaspora tourism of the Chinese diaspora. By investigating 303 overseas Chinese, we use quantitative methodologies to measure the nostalgia of the Chinese diaspora and identify three segments of Chinese diasporic tourists based on their nostalgia: extremely nostalgic, nostalgic, and moderately nostalgic. Demographic features of each segment and attitude toward home-return travel are depicted. The findings suggest that the level of nostalgia has influences on the perception of home-return travel for the diaspora. For the strongly nostalgic groups, homereturn travel is an important way to build and express their identity. For the moderately nostalgic group, home-return travel is regarded as a pleasure-driven activity. This study extends the theoretical understanding of diaspora nostalgia and also has practical implications for the marketing and construction of destinations.
\end{abstract}

Keywords: nostalgia; involvement; home-return travel; diaspora; overseas Chinese

\section{Introduction}

The number of international migrants has shown a growing trend over the last two decades. In 2019, the number of international migrants worldwide reached 272 million, accounting for $3.5 \%$ of the global population [1]. The idea of returning home is very often important for migrants [2], as the desire to relive and revisit places in the past is often deeply rooted in the diaspora community [3]. In the past, due to the limitation of geographic distance, political context, and economic considerations, it was rather difficult, even impossible, for migrants to revisit their homeland. However, the development of modern technology has made traveling to homeland convenient and affordable. For modern diaspora, homecoming is no longer regarded as a "once-in-a-lifetime experience" but as a form of tourism. Under globalization and with the growing mobility, diaspora tourism has become a significant market niche.

Nostalgia is an important reason for the diaspora to embark on journeys to their ancestors' lands [4]. Nostalgia was first coined to describe a homesickness disease and was later regarded as "a painful yearning to return home" [5]. Tourism scholars have commented on the role of nostalgia in tourism behavior [6-12] in diverse settings, such as film tourism [13,14], heritage tourism [15], cultural tourism [16], and sport tourism [17]. It has been found that nostalgia is a powerful stimulus for traveling and has enhanced destination loyalty [18].

In the Chinese context, nostalgia, referred to as Xiangchou, is often associated with longing for things of the past, which means nostalgic feelings and attachment for the natural and human landscape of homeland. China's rapid urbanization and modernization have led to dramatic changes in urban and rural landscapes, and traditional lifestyles are disintegrating. The Chinese government has launched the "retain nostalgia" program in 
2013. In "Strategic Plan for Rural Revitalization (2018-2022)", the government has proposed to "retain the memories of nostalgia" and "reproduce the original rural scenery and the original nostalgia". Remembering nostalgia, preserving rural memories, and inheriting and revitalizing rural culture have become important missions for rural construction and cultural revival. There is a 50 million-strong Chinese diaspora, and most ancestral homelands for overseas Chinese are in rural areas. Thus, how to retain and remember nostalgia in the process of rural revitalization is of great significance to the sustainable development of rural areas and is an important means to obtain overseas Chinese emotional recognition, social value recognition, and identity recognition.

Diaspora tourism to China has become a sizable and lucrative market segment. Despite the growing size of the diaspora tourism market, there is still a lack of academic research on diaspora tourism to China. Researchers have examined the influence of diaspora tourism on migrant identity and attachment to the homeland from the perspective of place attachment, cultural identity [19], well-being [20], and cultural connectedness. There is scant research on what constitutes diaspora's nostalgia and how nostalgia stimulates diaspora tourism. No previous studies have used quantitative methodologies to quantify and deconstruct nostalgia in diaspora tourism settings and examine the influence of nostalgia on diasporic home-return travel. In the context of China's new urbanization construction, it is of great importance to study how nostalgia stimulates diaspora's travel behavior intentions and how diaspora tourism promotes rural revitalization and the sustainable development of rural destinations.

Responding to this research gap, the purpose of this study is to examine the multidimensional nostalgia in the setting of diaspora tourism by quantitative methodologies and explore the influence of nostalgia on involvement and behavior intentions to engage in home-return travel of diasporic tourists. The current study examines the following research questions:

(1) What constitutes diaspora's nostalgia?

(2) How does nostalgia influence diasporic tourists' involvement with home-return travel?

(3) To what extend does nostalgia affect the diasporic tourists' home-return travel?

(4) How to identify and develop new target markets to promote the sustainable development of rural tourism?

To address these issues, this study segments Chinese diasporic tourists based on the level of nostalgia and discusses the influence of nostalgia on home-return travel. The current study attempts to extend the understanding of the nostalgia of the Chinese diaspora and apply it in the development of destinations to attract overseas Chinese home-return travel.

\section{Literature Review}

\subsection{Nostalgia}

The word nostalgia was firstly coined by Swiss physician Johannes Hofer in the late 17 th century to describe the disease suffered by the soldiers away from home. Today nostalgia is no longer looked upon by the medical profession as a disease, and various definitions of nostalgia from a psychological perspective have been given by scholars. For example, Davis (1979) regarded nostalgia as a painful desire or a painful yearning to return home [5]. Other authors argue that nostalgia is more than a "homing instinct". It is a result of dissatisfaction from modernization, a yearning for a secure and stable existence in a more acceptable world [2]. Therefore, the concept of nostalgia not only refers to the longing for home but has been broadened to describe a sentimental longing for something far away, something with spatial and temporal distance. The temporal distance is not limited to one's own past experiences but also includes a collective past such as history. Stern (1992) categorized nostalgia into "personal nostalgia" and "historical nostalgia" [21], the former denoting a sentimental longing for a return to one's personally remembered past and the latter referring to a desire to return to the distant past viewed as superior to the present. 
In the Chinese context, nostalgia is often associated with longing for things of the past, which means nostalgic feelings and attachment for the natural and human landscape of homeland. The spatial carries of nostalgia can be the countryside or the city where the obsolete or nostalgic atmosphere triggers their memories of the past. Liu pointed out that nostalgia not only refers to the memories and soft emotions of missing homeland or the lived place, but it is also a cultural feeling, enlightenment or sense of identity [22]. Nostalgia is the emotion, memory, and expectation of homeland [23], and rural area is the spiritual home for rural residents and nostalgic people to store their nostalgia [24]. China's rapid urbanization and modernization have led to dramatic changes in urban and rural landscapes, and traditional lifestyles are disintegrating. People reminisce about the past physical space, past cultural memories, cultural feelings, and cultural identity. Research on nostalgia from the perspective of geography, architecture, and sociology shows a blowout growth [25]. The focus has gradually shifted from the research on the connotation and expression of nostalgia to the in-depth study of the theory and mechanism of how to effectively integrate the concept of nostalgia into urbanization construction to promote the healthy development of urbanization and improve the quality of urbanization.

\subsection{Nostalgia and Tourism}

Tourism scholars have noticed the relations between nostalgia and tourism. Modernity is the bridge that connects nostalgia and tourism. Modernity forces people to look for authenticity by traveling to other places, and nostalgia is dissatisfaction with modernity, a yearning for positive past memories before modernization. Nostalgia and tourism are both effective ways for people to escape from modernity. Nostalgia is an escape in time, leaving now for then, while tourism is an escape in space, leaving here for there.

Scholars have studied the triggers of nostalgia in tourism settings. It is found that both tangible and intangible elements can be the triggers of nostalgia. These tangible or intangible elements that address the senses, such as seeing, hearing, and smelling, are able to evoke nostalgic feelings. Traditional food at a theme restaurant, specific scents and odors, nostalgic music, conversations and exchange of old stories, nostalgic design of the venue, etc., can all act as stimulators of nostalgia. Chen et al. (2014) found that nostalgia had impacts on the consumption intentions of customers in nostalgic-themed restaurants of Taiwan [26]. The nostalgic elements in tourism venues offer tourists temporal idealization towards the free, innocent, and pure past and give them elements in pursuit of authenticity.

Nostalgia has been an intrinsic motivation for travel, and nostalgia-oriented tourism has attracted researchers' attention [16]. Leong et al. (2015) examined nostalgia as a push motive and explored its influence on tourists' loyalty behaviors, supportive behavior, and future visit intention in visiting cultural tourism destinations [27]. Meng et al. (2019) found that nostalgia is the key push factor that stimulates rural-urban migrant tourists to visit rural regions [28].

Nostalgia adds value to the tourist overall experience as it satisfies tourists nostalgic needs and leads to future visit intentions. Gao et al. (2020) found the nostalgic experience had a positive role in visitor satisfaction at reused heritage sites [29]. Other researchers found that nostalgia had positive effects on the perceived value of destination, memorable travel experience [30], and revisit intention [31].

The importance of nostalgia within the tourism context is widely accepted. The majority of nostalgia-tourism-related studies have provided useful insights on whether travel is motivated by nostalgia and whether tourism provides a nostalgic experience. The measurement of diaspora's nostalgia and nostalgic feelings to the homeland has rarely been studied. The current studies have yet to answer how nostalgia stimulates travel behavior intentions and the extent to which travel experience can satisfy people's nostalgic needs.

\subsection{Diaspora Tourism}

Diaspora tourism usually refers to people of migrant origins visiting their ancestral homeland [4]. Researchers have studied diaspora tourism of different nations. Ranjan 
(2008) explored the influence of Bollywood movies on diaspora tourism to India [14]. Howard and Danielle (2010) explored the influence of 'homeland' on holidays of the Irish diaspora [32]. Murdy et al. (2018) studied the motivations of ancestral tourists of the Scotish diaspora [33].

Compared with other groups, diaspora tourism to China has been less studied [34]. Most cross-border tourism studies treat China as a source country for outbound tourism, not as a destination for overseas Chinese returning home. The current Chinese diaspora tourism studies mainly investigate the return travel by Chinese immigrants in North America [34-36]. Li and McKercher explored the relationship between place attachment and home return travel [19]. They found that place attachment on different spatial scale lead to different home return travel patterns. On the other hand, the diasporic travel has impact on one's place attachment and cultural identity [34]. Engagement with homereturn travel is helpful to create meaning and purpose in life and will lead to eudaimonic well-being [36].

Most of the current studies on diaspora tourism are based on the place attachment theory. There is scant research on how nostalgia stimulates diaspora tourism and no previous study has used quantitative methodologies to examine the structural relationships of multidimensional nostalgia in the setting of diaspora tourism. What constitutes diaspora's nostalgia and how do these factors influence their home-return travel remain unclear.

\subsection{Involvement}

Involvement is the level of perceived personal importance evoked by a stimulus (or stimuli) within a specific situation. Since the 1990s, the concept of involvement has been increasingly used in the research of leisure, recreation, and tourism [37]. In tourism, most researchers have assumed involvement as an antecedent of behavior [38,39]. As a motivational variable, involvement influences individuals' perception of a destination [40] and how strongly they are attached to the destination.

Researchers have proposed different scales for involvement measurement, for example, Laurent and Kapferer's consumer involvement profiles (1985) [41], Gursoy and Gavcar's three-dimensional construct (2003) [40], and Kyle and Chick's five leisure involvement dimensions (2004) [42]. It has been found that the degree of involvement affects individual's intention to participate in leisure activities and travel [43], and the level of involvement has a positive influence on satisfaction with the travel experience [44]. On the other hand, the tourists' own resources and behaviors, i.e., skills and knowledge, physical, social, and cultural resources, act as influencers of the tourist involvement in the conception and design of their experiences [37].

There are two dimensions of involvement: psychological involvement and behavioral involvement $[45,46]$. Psychological involvement with home-return travel can be expressed as a type of psychological effort or attitudinal attachment with the travel, such as importance, pleasure, or self-expression [47]. That is, those who are psychologically involved with home-return travel consider it as important, pleasurable, and as a means by which to express self-value. Latent psychological states often result in observable behavior, so the psychological involvement with home-return travel may lead to other behavioral pursuits. Thus, behavioral involvement with home-return travel can refer to purchasing homeland-related products, discussing home-return travel, searching for information, and updating news on home-return travel.

\section{Methodology}

\subsection{Study Area and Sampling}

This study aimed to examine the nostalgia of the Chinese diaspora and its influence on their home-return travel. Specifically, overseas Chinese whose ancestral homeland is Fujian were selected as the target population. Lying on the southeastern coast of China, Fujian is a famous and important ancestral hometown of overseas Chinese, as shown in Figure 1. People in Fujian had a long history of migration, which can be traced back to the 17th 
century. During the Ming and Qing Dynasties, more than 100,000 people of Fujian origin resided in Southeast Asia. From the mid-19th century to the early 20th century, the number of people going abroad reached 1.168 million, and many of them were contract Chinese laborers. The "old overseas Chinese" (Laohuaqiao) who migrated during or before the 1950s mainly resided in Southeast Asian countries, such as Malaysia, Indonesia, Philippines, Singapore, etc. After the introduction of the Reform and Opening-up Policy in 1978, the Chinese government gradually loosened the limits of migration. More than 1.1 million "new overseas Chinese" from Fujian have settled abroad and distributed in 156 countries and regions. Immigrant destinations for the "new overseas Chinese" have shifted from traditional Southeast Asian countries to developed countries in Europe and America, such as the USA, Canada, Australia, Britain, France, etc. Most of the new Chinese migrants grew up in mainland China, cared about the development of their motherland, and strove to maintain their Chineseness after migration. Nowadays, among the 50 million-strong overseas Chinese worldwide, 15.8 million are with the origin of Fujian.

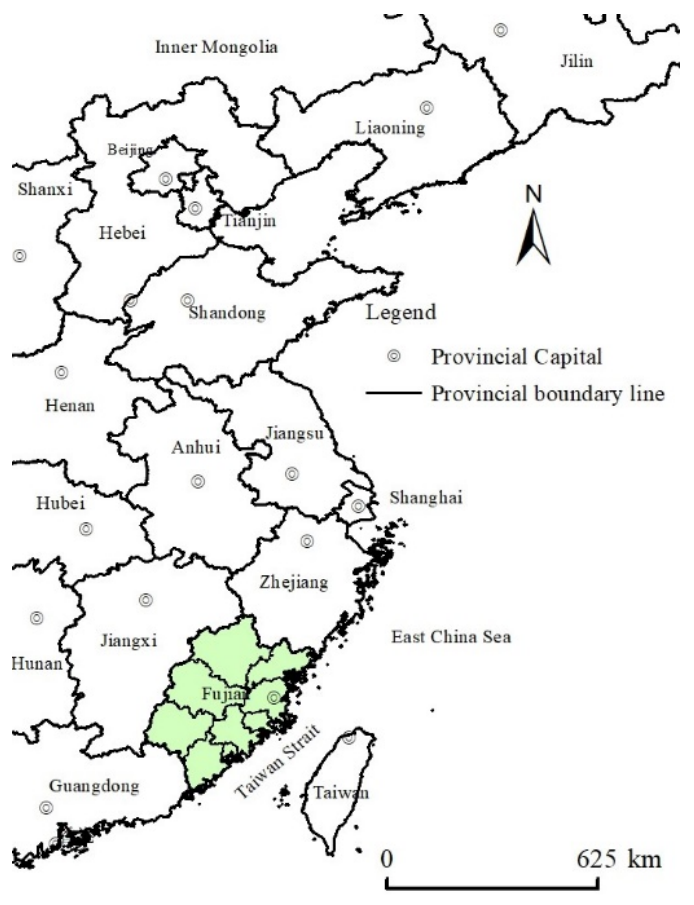

Figure 1. Location of the Fujian Province.

\subsection{Questionnaire Design}

The questionnaire consisted of four parts. Part 1 dealt with the measurement of nostalgia. The nostalgia measurement scale was drawn from Cho et al. (2017) [48] and Cho et al. (2019) [49]. Items were modified according to the context of diaspora tourism and home-return travel. Part 2 dealt with the measurement of involvement. The involvement scale was drawn from the measurement scale of Laurent and Kapferer [41], Gursoy and Gavcar [40], and A.C. Campos et al. [37]. Part 3 dealt with the measurement of behavior intentions. A five-point Likert scale ranging from 1 (strongly disagree) to 5 (strongly agree) was adopted to evaluate the items. Part 4 presented respondents' demographic information with eight items to investigate their social background and home-return experience. Social background included gender, age group, education, generation, job category, nationality, and country of residence.

The items were first developed and written in English and afterwards translated into Chinese, back-translated, and then retranslated to ensure comparability of data between the English and Chinese versions of the questionnaire. 


\subsection{Data Collection}

A pilot study was conducted to assess the items, evaluate the layout and length of the questionnaire, and identify any potential problems in the questionnaire design. The internal reliability of the scales was assessed in this stage using Cronbach's alpha. The results showed that the Cronbach's alphas of each construct were all exceeding the cutoff of 0.60. Items with low factor loadings (less than 0.50) were eliminated. Finally, 13 out of 27 items measuring nostalgia and 8 out of 13 items measuring involvement were retained after the EFA and used in the main survey.

\subsection{Data Analysis}

Various statistical approaches were utilized to analyze data. A descriptive analysis was performed to profile the respondent characteristics. Exploratory factor analysis was performed to identify the underlying dimensions of nostalgia of the Chinese diaspora. After confirming the latent structure of nostalgia, cluster analysis was employed to identify Chinese diasporic tourists. Moreover, a series of multiple analysis of variance (MANOVA) and analysis of variance (ANOVA) was conducted to detect the differences among the segments. Finally, multiple regression analyses were conducted to assess the effect of nostalgia on home-return travel involvement and intention.

\section{Findings}

\subsection{Demographic Profile of Respondents}

Data collection for this study took place from December 2020 to February 2021, when it was the Spring Festival of the Year of the Ox. Many overseas Chinese returned to their homeland during this period of time, which provided good opportunities to conduct the survey. A total of 303 fully completed questionnaires were collected, validated, and included in the analysis.

Table 1 presents the demographic profile of respondents. There were slightly more males $(52.1 \%)$ than females $(47.9 \%)$. The age distributions were fairly even. Overall, $51.2 \%$ of the respondents were of Chinese nationality, while $48.8 \%$ obtained the nationality of the living country. $31.4 \%$ of the respondents lived in the Philippines, and the rest lived in Singapore, Malaysia, Thailand, Canada, Japan, America, Australia, Britain, Spain, and Italy.

In terms of migrant generation, first-generation migrants mean that they were born in China and then migrated to the resident countries. Second-generation migrants mean that at least one of their parents was born in China and migrated to resident countries, and they themselves were native born in resident countries. Third-generation migrants have at least one China-born grandparent, and fourth-generation or more means their grandparents were all born in resident countries. A total of $36.0 \%$ of the respondents were first-generation migrants, and $37.6 \%$ were second-generation migrants.

\subsection{Exploratory Factor Analysis}

Three constructs (nostalgia, involvement, and behavior intention) were measured. Exploratory factor analysis (EFA) was conducted to identify the underlying dimensions of Chinese diaspora nostalgia. The data were analyzed using principal axis factoring with a Promax rotation in SPSS 23.0. Results revealed that 13 nostalgia indicators generated five underlying factors with eigenvalues greater than 1.0. Items with low factor loadings (less than 0.50 ) were eliminated. The five extracted factors explained $65.4 \%$ of the total variance. The Cronbach's alphas scores for the five factors were greater than 0.60 , suggesting the internal consistency of items within each factor. Finally, five dimensions of nostalgia were identified, namely, personal identity, socialization, group identity, homeland experience, and homeland environment (Table 2). 
Table 1. Demographic profile of respondents.

\begin{tabular}{|c|c|c|c|}
\hline Variables & Category & Numbers & Frequency \\
\hline \multirow{2}{*}{ Gender } & Male & 158 & $52.1 \%$ \\
\hline & Female & 145 & $47.9 \%$ \\
\hline \multirow{5}{*}{ Age } & $18-29$ & 59 & $19.5 \%$ \\
\hline & 30-39 & 107 & $35.3 \%$ \\
\hline & $40-49$ & 71 & $23.4 \%$ \\
\hline & $50-59$ & 42 & $13.9 \%$ \\
\hline & $\geq 60$ & 24 & $7.9 \%$ \\
\hline \multirow{2}{*}{ Nationality } & Chinese & 155 & $51.2 \%$ \\
\hline & Others & 148 & $48.8 \%$ \\
\hline \multirow{11}{*}{ Country of residence } & Philippines & 95 & $31.4 \%$ \\
\hline & Singapore & 31 & $10.2 \%$ \\
\hline & Malaysia & 27 & $8.9 \%$ \\
\hline & Thailand & 26 & $8.6 \%$ \\
\hline & Japan & 25 & $8.3 \%$ \\
\hline & Canada & 23 & $7.6 \%$ \\
\hline & America & 21 & $6.9 \%$ \\
\hline & Australia & 17 & $5.6 \%$ \\
\hline & Britain & 15 & $4.9 \%$ \\
\hline & Spain & 13 & $4.3 \%$ \\
\hline & Italy & 10 & $3.3 \%$ \\
\hline \multirow{4}{*}{ Generation } & 1-generation & 109 & $36.0 \%$ \\
\hline & 2-generation & 114 & $37.6 \%$ \\
\hline & 3-generation & 65 & $21.5 \%$ \\
\hline & 4-generation or more & 15 & $4.9 \%$ \\
\hline \multirow{5}{*}{ Education } & High school & 66 & $21.8 \%$ \\
\hline & College/vocational training & 99 & $32.7 \%$ \\
\hline & University & 98 & $32.3 \%$ \\
\hline & Master's & 34 & $11.2 \%$ \\
\hline & $\mathrm{PhD}$ & 6 & $2.0 \%$ \\
\hline \multirow{3}{*}{ Job category } & Student/unemployed & 38 & $12.5 \%$ \\
\hline & Non-specialized occupation & 113 & $37.3 \%$ \\
\hline & Specialized occupation & 152 & $50.2 \%$ \\
\hline
\end{tabular}

Table 2. The results of exploratory factor analysis for nostalgia.

\begin{tabular}{|c|c|c|c|c|c|}
\hline Factors & Items & $\begin{array}{l}\text { Factor } \\
\text { Loading }\end{array}$ & Eigenvalue & $\begin{array}{l}\text { Variance } \\
\text { Explained }\end{array}$ & Cronbach's $\alpha$ \\
\hline \multirow{4}{*}{$\begin{array}{l}\text { Personal Identity } \\
\qquad(\mathrm{PI})\end{array}$} & $\begin{array}{l}\text { I have a feeling of satisfaction as a } \\
\text { Chinese migrant. }\end{array}$ & 0.717 & \multirow{4}{*}{2.154} & \multirow{4}{*}{16.6} & \multirow{4}{*}{0.685} \\
\hline & $\begin{array}{l}\text { I have positive feelings about myself as a } \\
\text { Chinese migrant. }\end{array}$ & 0.708 & & & \\
\hline & $\begin{array}{l}\text { I have a sense of accomplishment as a } \\
\text { Chinese migrant. }\end{array}$ & 0.702 & & & \\
\hline & I feel pride in being a Chinese migrant. & 0.627 & & & \\
\hline \multirow{3}{*}{$\begin{array}{l}\text { Socialization } \\
\qquad(\mathrm{SA})\end{array}$} & $\begin{array}{l}\text { I like the entertainments enjoyed with } \\
\text { others during social events related } \\
\text { to China. }\end{array}$ & 0.791 & \multirow{3}{*}{1.818} & \multirow{3}{*}{14.0} & \multirow{3}{*}{0.663} \\
\hline & $\begin{array}{l}\text { I like making new Chinese migrant } \\
\text { friends during social events related } \\
\text { to China. }\end{array}$ & 0.731 & & & \\
\hline & $\begin{array}{l}\text { I like socializing with others during } \\
\text { social events related to China. }\end{array}$ & 0.721 & & & \\
\hline
\end{tabular}


Table 2. Cont.

\begin{tabular}{|c|c|c|c|c|c|}
\hline Factors & Items & $\begin{array}{l}\text { Factor } \\
\text { Loading }\end{array}$ & Eigenvalue & $\begin{array}{l}\text { Variance } \\
\text { Explained }\end{array}$ & Cronbach's $\alpha$ \\
\hline \multirow{2}{*}{$\begin{array}{l}\text { Group identity } \\
\text { (GI) }\end{array}$} & I like the group rituals of my ethnicity. & 0.808 & \multirow{2}{*}{1.565} & \multirow{2}{*}{12.0} & \multirow{2}{*}{0.610} \\
\hline & I like the traditions of my ethnicity. & 0.785 & & & \\
\hline \multirow{2}{*}{$\begin{array}{l}\text { Homeland } \\
\text { experience } \\
\text { (HEP) }\end{array}$} & $\begin{array}{l}\text { I often remember the traditional activities } \\
\text { I enjoyed in China. }\end{array}$ & 0.840 & \multirow{2}{*}{1.504} & \multirow{2}{*}{11.6} & \multirow{2}{*}{0.634} \\
\hline & $\begin{array}{l}\text { I often think about my past experience } \\
\text { in China. }\end{array}$ & 0.785 & & & \\
\hline \multirow{2}{*}{$\begin{array}{l}\text { Homeland } \\
\text { environment } \\
\text { (HEI) }\end{array}$} & $\begin{array}{l}\text { I like the traditional music (folk songs) } \\
\text { of China. }\end{array}$ & 0.885 & \multirow[b]{2}{*}{1.464} & \multirow[b]{2}{*}{11.3} & \multirow[b]{2}{*}{0.619} \\
\hline & $\begin{array}{l}\text { I like the traditional equipment used in } \\
\text { China (such as the planting and } \\
\text { worshiping utensils). }\end{array}$ & 0.768 & & & \\
\hline
\end{tabular}

The eight involvement items were factor analyzed and resulted in three factors: pleasure/interest, sign value, and risk probability and consequence. The three extracted factors explained $65.1 \%$ of the total variance. Behavior intention was measured by three items, which explained $60.5 \%$ of the total variance (Table 3 ).

Table 3. The results of exploratory factor analysis for involvement and behavior intention.

\begin{tabular}{|c|c|c|c|c|c|c|}
\hline & Factors & Items & $\begin{array}{l}\text { Factor } \\
\text { Loading }\end{array}$ & Eigenvalue & $\begin{array}{l}\text { Variance } \\
\text { Explained }\end{array}$ & Cronbach's $\alpha$ \\
\hline \multirow{8}{*}{ Involvement } & \multirow{4}{*}{$\begin{array}{l}\text { Pleasure/Interest } \\
\text { (PL) }\end{array}$} & $\begin{array}{l}\text { Home-return travel experience } \\
\text { interests me a lot. }\end{array}$ & 0.725 & \multirow{4}{*}{1.920} & \multirow{4}{*}{24.0} & \multirow{4}{*}{0.636} \\
\hline & & $\begin{array}{l}\text { The home-return travel } \\
\text { experience is somewhat of a } \\
\text { pleasure to me. }\end{array}$ & 0.704 & & & \\
\hline & & $\begin{array}{l}\text { Participating in home-return } \\
\text { travel is like giving a gift } \\
\text { to myself. }\end{array}$ & 0.668 & & & \\
\hline & & $\begin{array}{l}\text { I attach great importance to } \\
\text { home-return travel experience. }\end{array}$ & 0.584 & & & \\
\hline & \multirow{2}{*}{$\begin{array}{l}\text { Risk probability } \\
\text { and consequence } \\
\text { (RP) }\end{array}$} & $\begin{array}{l}\text { If my home-return trip does not } \\
\text { go well, I will be very upset. }\end{array}$ & 0.883 & \multirow{2}{*}{1.654} & \multirow{2}{*}{20.7} & \multirow{2}{*}{0.724} \\
\hline & & $\begin{array}{c}\text { It is really annoying if my } \\
\text { home-return trip is not suitable. }\end{array}$ & 0.786 & & & \\
\hline & \multirow[t]{2}{*}{ Sign value (SV) } & $\begin{array}{c}\text { You can tell a lot about a person } \\
\text { by whether or not he/she } \\
\text { chooses to have } \\
\text { home-return travel. }\end{array}$ & 0.834 & \multirow[t]{2}{*}{1.635} & \multirow[t]{2}{*}{20.4} & \multirow[t]{2}{*}{0.686} \\
\hline & & $\begin{array}{l}\text { Most of my friends are in some } \\
\text { way connected with } \\
\text { home-return travel. }\end{array}$ & 0.769 & & & \\
\hline \multicolumn{7}{|c|}{ Cumulative $\%=65.1, \mathrm{KMO}=0.745$, Bartlett's Chi-Square $=499.621(\mathrm{df}=28, p<0.000)$} \\
\hline \multirow{3}{*}{\multicolumn{2}{|c|}{ Behavior Intention (BI) }} & $\begin{array}{l}\text { I will consider visiting } \\
\text { homeland the first choice } \\
\text { of traveling. }\end{array}$ & 0.795 & \multirow{3}{*}{1.816} & \multirow{3}{*}{60.5} & \multirow{3}{*}{0.674} \\
\hline & & I intend to visit homeland. & 0.772 & & & \\
\hline & & $\begin{array}{l}\text { (If I have children) I will bring } \\
\text { my children to visit homeland. }\end{array}$ & 0.767 & & & \\
\hline \multicolumn{7}{|c|}{$\mathrm{KMO}=0.662$, Bartlett's Chi-Square $=136.189(\mathrm{df}=3, p<0.000)$} \\
\hline
\end{tabular}




\subsection{Segmenting Chinese Diasporic Tourists}

Cluster analysis was performed based on respondents' nostalgia levels. This study used hierarchical cluster analysis and K-means cluster analysis in non-hierarchical cluster analysis. Although K-means clustering analysis has advantages when categorizing large amounts of data, the interpretation of results varies depending on the number of clusters. Therefore, it is important to determine the number of clusters first. The approximate distance coefficients in the agglomeration schedule of the hierarchical cluster analysis were used to determine the number of clusters. Table 4 shows the results of the cluster analysis. A series of MANOVA and ANOVA tests was conducted to examine the different nostalgia factors across the clusters. LSD post hoc analysis confirmed that there are significant differences across the clusters.

Table 4. Clusters analysis of Chinese diaspora $(N=303)$.

\begin{tabular}{|c|c|c|c|c|c|c|c|}
\hline & \multirow{2}{*}{$\begin{array}{c}\text { Cluster I } \\
(N=162 / 53.5 \%)\end{array}$} & \multirow{2}{*}{$\begin{array}{c}\text { Cluster II } \\
(N=78 / 25.7 \%)\end{array}$} & \multirow{2}{*}{$\begin{array}{c}\text { Cluster III } \\
(N=63 / 20.8 \%)\end{array}$} & \multirow{2}{*}{$\mathbf{F}$} & \multicolumn{3}{|c|}{ LSD Post Hoc Analysis } \\
\hline & & & & & I-II & II-III & I-III \\
\hline PI & 4.31 & 4.18 & 3.73 & $\underset{* * *}{38.25}$ & $* *$ & $* * *$ & $* * *$ \\
\hline SA & 4.19 & 4.21 & 3.60 & $\begin{array}{c}35.85 \\
* * *\end{array}$ & $\mathrm{n} / \mathrm{s}$ & $* * *$ & $* * *$ \\
\hline GI & 4.58 & 4.64 & 3.84 & $\underset{* * *}{70.02}$ & $\mathrm{n} / \mathrm{s}$ & $* * *$ & $* * *$ \\
\hline HEP & 4.65 & 3.73 & 3.55 & $\begin{array}{c}301.97 \\
* * *\end{array}$ & $* * *$ & $* * *$ & $* * *$ \\
\hline HEI & 4.38 & 4.60 & 3.77 & $\underset{* * *}{44.71}$ & $* * *$ & $* * *$ & $* * *$ \\
\hline & & & & \multicolumn{4}{|c|}{$\begin{array}{l}\text { Pillai's Trace: } 1.132 * * * \\
\text { Wilks' Lambda: } 169^{* * *} \\
\text { Hotelling's Trace: } 3.142^{* * *} \\
\text { Roy's Largest Root: } 2.401^{* * *}\end{array}$} \\
\hline
\end{tabular}

Cluster I represented $53.5 \%$ of the total respondents, with all five factors scoring high. They are thus labeled as "extremely nostalgic". This group included respondents who have actual experience of living in their homeland $\left(\mathrm{M}_{\mathrm{HEP}}=4.65\right)$ and still have strong and abundant physical and social ties with people in their homeland. They have positive feelings as being overseas Chinese $\left(\mathrm{M}_{\mathrm{PI}}=4.31\right)$. They enjoy socializing with Chinese or Chinese migrants and are willing to conduct actions to maintain their proximity to their homeland. They are highly attached to their homeland and often think about their homeland environment. To a large extent, their strong nostalgia is engendered by their homeland experience and socialization with both things and people from their homeland. As shown in Table 5, 60.5\% of respondents in this group have Chinese nationality, and the average age is 52.2 years. The percentage of women (46.3\%) is a bit lower than that of men $(53.7 \%)$. This group has the highest percentage of first-generation migrants $(51.8 \%)$, followed by second-generation migrants (33.3\%). The majority of people in this segment have basic education (the percentage of those with high school or college education sum to $58 \%)$ and are engaged in specialized occupations (51.2\%).

Cluster II represented $25.7 \%$ of the respondents. Unlike Cluster I, whose nostalgia is based on their homeland experience, this group is characterized by individuals whose nostalgia is identity-based. This group is characterized by individuals with the homeland experience dimension rated slightly lower than the other four dimensions, but the homeland environment rated comparatively high. They are thus labeled as "nostalgic". This group consists of people whose object connection with their homeland is fading. They have little or may even have no actual experience of living in their homeland. Their understanding of China is based on the family tradition, identity, group identity and socialization with China-related activities. Their nostalgic feelings may be evoked by daily 
activities, events, or social gatherings of the family and community. They have limited actual connection with their homeland but are immersed in homeland-rated environment, which make them more longing for their homeland environment. Thus, people in this group perceive group identity and homeland environment more highly than people in Cluster I. A total of $48.7 \%$ of respondents in this group have Chinese nationality, and the average age of this group is 42.3 years. The percentage of women in this segment (52.8\%) is higher than the percentage of men. Second-generation migrants $(48.7 \%)$ are the most common, followed by first-generation migrants $(21.8 \%)$ and third-generation migrants $(20 \% .5)$. Similar to Group I, the majority of people have basic education (the percentage of those with high school or college education sum to $57.7 \%$ ) with a specialized occupation.

Table 5. Summary of demographic variables of each cluster.

\begin{tabular}{|c|c|c|c|c|}
\hline Variable & Total & Cluster 1 & Cluster 2 & Cluster 3 \\
\hline Size & 303 & 162 & 78 & 63 \\
\hline Age & & 52.2 & 42.3 & 24.3 \\
\hline \multicolumn{5}{|l|}{ Gender } \\
\hline Women & 145 & $46.3 \%$ & $51.3 \%$ & $47.6 \%$ \\
\hline Men & 158 & $53.7 \%$ & $48.7 \%$ & $52.4 \%$ \\
\hline \multicolumn{5}{|l|}{ Generation } \\
\hline 1-generation & 109 & $51.8 \%$ & $21.8 \%$ & $12.7 \%$ \\
\hline 2-generation & 114 & $33.3 \%$ & $48.7 \%$ & $32.4 \%$ \\
\hline 3-generation & 65 & $13.0 \%$ & $20.5 \%$ & $41.2 \%$ \\
\hline 4-generation or more & 15 & $1.9 \%$ & $9.0 \%$ & $7.9 \%$ \\
\hline \multicolumn{5}{|l|}{ Education } \\
\hline High school & 66 & $24.7 \%$ & $19.2 \%$ & $17.5 \%$ \\
\hline College/vocational training & 99 & $33.3 \%$ & $38.5 \%$ & $23.8 \%$ \\
\hline University & 98 & $30.9 \%$ & $30.8 \%$ & $38.1 \%$ \\
\hline Master's & 34 & $9.3 \%$ & $9.0 \%$ & $19.0 \%$ \\
\hline PhD & 6 & $1.9 \%$ & $2.5 \%$ & $1.6 \%$ \\
\hline \multicolumn{5}{|l|}{ Job category } \\
\hline Student/unemployed & 38 & $7.4 \%$ & $14.1 \%$ & $22.1 \%$ \\
\hline Non-specialized occupation & 113 & $41.4 \%$ & $33.3 \%$ & $29.4 \%$ \\
\hline Specialized occupation & 152 & $51.2 \%$ & $52.6 \%$ & $41.2 \%$ \\
\hline \multicolumn{5}{|l|}{ Nationality } \\
\hline Chinese & 155 & $60.5 \%$ & $48.7 \%$ & $30.2 \%$ \\
\hline Others & 148 & $39.5 \%$ & $51.3 \%$ & $69.8 \%$ \\
\hline
\end{tabular}

Cluster III represented $20.8 \%$ of the respondents. This group consists of people with the lowest perception of nostalgia and is thus labeled as "moderately nostalgic". They tend to be less connected with homeland as the homeland experience dimension rated the lowest. Group identity dimension rated slightly higher than other four dimensions. They have rare actual experience of living in their homeland and may live in families and communities that do not value the traditions and activities related to the homeland. Only $30.2 \%$ of this group have Chinese nationality, and the average age of this group is much younger ( 24.3 years old) than the other two groups. The percentage of women is $47.6 \%$. This group has the highest percentage of third-generation migrants $(41.2 \%)$, followed by second-generation migrants (32.4\%). People with a university education $(38.1 \%)$ are the most common, and $20.6 \%$ of the participants have a master's degree or PhD. Specialized occupation is also the most common job category in this segment (41.2\%).

A discriminant analysis was then performed to validate the cluster classification (Table 6). The factor of homeland experience and group identity appeared to be important in the first discriminant function in segregating the clusters. The factor of socialization, homeland environment, and group identity was important for differentiating the clusters in the second function. The leave-one-out cross-validation approach was used to cross-validate the classification. It turned out that $98.7 \%$ of the cases in the original data 
were correctly classified, while $98.7 \%$ of the cross-validated groups' cases were correctly classified. This demonstrates the accuracy of the classification.

Table 6. Discriminant analysis results $(N=303)$.

\begin{tabular}{|c|c|c|c|c|c|c|}
\hline Function & Eigenvalue & $\begin{array}{l}\text { Percentage of } \\
\text { Variance } \\
\text { Explained by } \\
\text { Function }\end{array}$ & \multicolumn{2}{|c|}{ Canonical Correlation } & Wilks' Lambda & Chi-Square \\
\hline 1 & 2.401 & 76.4 & \multicolumn{2}{|c|}{0.840} & 0.169 & $530.023^{* * *}$ \\
\hline 2 & 0.741 & 23.6 & \multicolumn{2}{|c|}{0.652} & 0.574 & $165.283 * * *$ \\
\hline \multirow{4}{*}{$\begin{array}{c}\text { Standardized canonical } \\
\text { discriminant function } \\
\text { coefficients }\end{array}$} & Function & PI & SA & GI & HEP & HEI \\
\hline & 1 & 0.290 & 0.164 & 0.412 & 0.798 & 0.302 \\
\hline & 2 & 0.042 & 0.512 & 0.498 & -0.606 & 0.568 \\
\hline & & Cluster I & \multicolumn{2}{|c|}{ Cluster II } & Cluster III & \\
\hline \multirow{3}{*}{ Primitive value } & Cluster I & $162(100 \%)$ & \multicolumn{2}{|c|}{0} & 0 & $162(100 \%)$ \\
\hline & Cluster II & 0 & \multicolumn{2}{|c|}{ 77(98.7\%) } & $1(1.3 \%)$ & $78(100 \%)$ \\
\hline & Cluster III & $3(4.8 \%)$ & \multicolumn{2}{|c|}{0} & $60(95.2 \%)$ & $63(100 \%)$ \\
\hline \multirow{3}{*}{ Cross-validation } & Cluster I & $162(100)$ & \multicolumn{2}{|c|}{0} & 0 & $162(100 \%)$ \\
\hline & Cluster II & 0 & \multicolumn{2}{|c|}{ 77(98.7\%) } & $1(1.3 \%)$ & $78(100 \%)$ \\
\hline & Cluster III & $3(4.8 \%)$ & \multicolumn{2}{|c|}{0} & $60(95.2 \%)$ & $63(100 \%)$ \\
\hline
\end{tabular}

${ }^{* * *} p<0.001 ; 98.7 \%$ of originally grouped cases were correctly classified; $98.7 \%$ of cross-validated groups' cases were correctly classified.

\subsection{The Relations of Nostalgia, Involvement, and Behavior Intention}

Eight involvement items and three behavior intention items of home-return travel were evaluated. A MANOVA test was conducted to examine the differences in each dimension of involvement and behavior intention of home-return travel across the clusters. LSD post hoc tests showed that there were significant differences existed between the first and third cluster and the second and third cluster. No significant differences were found between the first and second cluster in three dimensions of involvement except sign vale and behavior intention $(p>0.05)$ (Table 7).

Table 7. Results of cluster analysis for involvement and behavior intention $(N=303)$.

\begin{tabular}{|c|c|c|c|c|c|c|c|}
\hline & \multirow{2}{*}{ Cluster I Mean } & \multirow{2}{*}{ Cluster II Mean } & \multirow{2}{*}{ Cluster III Mean } & \multirow{2}{*}{ F-Value } & \multicolumn{3}{|c|}{ LSD Post Hoc Analysis } \\
\hline & & & & & I-II & II-III & I-III \\
\hline PL & 4.35 & 4.29 & 3.94 & $22.130^{* * *}$ & $\mathrm{n} / \mathrm{s}$ & $* * *$ & $* * *$ \\
\hline RP & 4.05 & 4.02 & 3.32 & $32.869 * * *$ & $\mathrm{n} / \mathrm{s}$ & $* * *$ & $* * *$ \\
\hline SV & 4.19 & 3.98 & 3.53 & $27.822 * * *$ & $* *$ & $* * *$ & $* * *$ \\
\hline $\mathrm{BI}$ & 4.65 & 4.65 & 4.16 & $32.972 * * *$ & $\mathrm{n} / \mathrm{s}$ & $* * *$ & $* * *$ \\
\hline
\end{tabular}

Pillai's Trace: $1.132^{* * *}$; Wilks' Lambda: $169^{* * * ;}$

Hotelling's Trace: $3.142{ }^{* * *}$; Roy's Largest Root: $2.401^{* * *}$

** $p<0.05 ;{ }^{* * *} p<0.01 ; \mathrm{n} / \mathrm{s}-$ not significant.

The mean involvement scores were the highest for Cluster I, followed by Cluster II, while Cluster III showed the lowest score. Both Cluster I and Cluster II received a high score in nostalgia $\left(\mathrm{M}_{\mathrm{I}}=4.422, \mathrm{M}_{\mathrm{II}}=4.272\right)$ and can be regarded as strongly nostalgic groups. The two strongly nostalgic groups were highly-involved in home-return travel and had a strong willingness to conduct home-return travel $\left(\mathrm{M}_{\mathrm{BI}}=4.65\right)$. For involvement and behavior intention, the strongly nostalgic groups (Cluster I and II) were clearly differentiated from the moderately nostalgic group (Cluster III). In other words, the level of nostalgia had a significant influence on the perception of home-return travel involvement and behavior intention.

Both Cluster I and Cluster II received a high score in nostalgia and were highly involved in home-return travel. The two strongly nostalgic groups had a strong perception 
of the pleasure and sign value of home-return travel. Significant differences were found at the 0.05 level in sign value between the two groups. That's due to the different origins of nostalgia. For Cluster I, their nostalgic feelings are mainly experience-based, but for Cluster II, their nostalgic feelings are mainly identity-based.

For people in Cluster III, they may not show strong nostalgia, but they were still willing to conduct home-return travel $\left(\mathrm{M}_{\mathrm{BI}}=4.16\right)$. They tend to conduct actions to maintain the proximity to their homeland. They are interested in home-return travel and regard it as a pleasure $\left(\mathrm{M}_{\mathrm{PI}}=3.94\right)$ but have a lower perception of sign value. For Cluster III, home-return travel is more like a pleasure-seeking journey.

\section{Discussion and Implication}

Most of the current studies on diaspora tourism are based on the place attachment theory. For example, Li and Chan [35] explored the multiple generations of overseas Chinese place attachment to China and how they sustained the attachment. Huang and Chen [34] examined the motivation of diaspora tourism and explored the impact of place attachment on travel motivation and intention. There is scant research on how nostalgia stimulates diaspora tourism, and no previous study has used quantitative methodologies to examine the structural relationships of multidimensional nostalgia in the setting of diaspora tourism. This study explores what constitutes diaspora's nostalgia and how these factors influence their involvement and behavior intention of home-return travel. A number of findings are notable.

First, Chinese diasporic tourists can be segmented into three clusters based on their level of nostalgia. Instead of treating the Chinese diaspora as a homogeneous market, this study segmented the Chinese diaspora tourists into three clusters based on their level of nostalgia so as to get a better understanding of their nostalgia and their perception of home-return travel. According to the appraisal theory of emotion [50], nostalgia is regarded as a positive emotion, which can trigger positive behaviors or behavioral tendencies and can enhance social connections and promote social interactions. Thus, the level of diaspora nostalgia has a significant influence on the perception of home-return travel involvement and behavior intention. The strongly nostalgic groups have a strong perception of the pleasure and sign value of home-return travel, while the moderately nostalgic group is more likely to take home-return travel as a pleasure-seeking journey. Their low level of nostalgia can be a result of limited physical connection with their homeland, but they are still interested in home-return travel and willing to be involved in traveling to China to seek pleasure and to seek things that remind them of their identity. This represents the characteristics of diaspora tourism. Unlike other types of tourists who travel to places to see things different from home, diaspora tourists are willing to seek things that remind them of their identity and home. Therefore, heterogeneous tourism products should be provided to satisfy the needs of diaspora tourists.

Second, two types of nostalgia in the context of diaspora tourism were identified: experience-based and identity-based. Consistent with previous studies [34,35], this study found that nostalgia can stem not only from the direct experience of a place but also as a consequence of hearing others' stories and memories of these places [47]. Experience-based nostalgia stems from direct contact with people, places, and experiences or things that are related to the homeland or homeland environments, such as facilities, equipment, and atmosphere. For those who have no actual living experience in their homeland, nostalgia can be evoked by identity (personal identity, group identity, and socialization). Culture and nationality are pre-destined and endogenous. No matter which country the diaspora lives in, the physical characteristics of their nationality, especially the characteristics of their own culture, are always difficult to discard and ignore.

Nostalgia can be evoked in the process of socialization. Individuals are connected to groups in various forms, such as family, friends, and social groups, and are exposed to social activities, such as daily activities, events, or social gatherings of the family and community. In overseas Chinese communities, socialization represented by Chinese gatherings and 
activities is an important way to enhance nostalgia and Chinese cultural identity. Through sharing interesting stories and experiences of homeland, the group members gradually solidify the core connotation of culture into the cultural characteristics of the Chinese community. Socialization and group activities among overseas Chinese communities are an important means to maintain their Chinese identity and an important source of nostalgia.

Third, home-return travel is related to national identity construction. Sign value is an important factor in distinguishing the groups. For strongly nostalgic groups, people tend to understand and identify themselves in the process of home-return travel. They might also come to the realization that home-return travel is an important way to build and express their identity. In other words, by participating in home-return travel activities, diaspora tourists can build the connection between individuals and ethnic groups and complete the construction of their own cultural identity. Home-return travel is a process of tourists' individual emotional experience and cultural identity.

Participating in group activities can also enhance the group-based experience that evokes nostalgic feelings. Traditional Chinese cultural festivals, memorial days, historical and cultural sites, cultural heritage, specific cultural landscapes, and other memorial places that carry collective memories of nations can all trigger the diaspora's positive response to conduct home-return travel. On the other hand, home-return travel enhances the interaction and communication between individuals and national history and national culture. Through home-return travel, diaspora tourists can implant the sense of national and cultural belonging into the individual's consciousness and form a sense of belonging and identity to the country.

Fourth, strongly nostalgic diaspora tourists are the new target markets to promote the sustainable development of rural tourism. It is shown by the findings that most overseas Chinese have a strong intention of home-return travel. The strongly nostalgic diaspora tourists who have homeland experience have a high perception of sign value and have a strong willingness to conduct home-return travel. On the other hand, home-return travel is an important way to build and express their identity. As most ancestral homelands for overseas Chinese are in rural areas, the Chinese diaspora can be regarded as an important target market for developing rural tourism. Through home-return travel, diasporic tourists can increase their hometown experience, and homeland experience can give them a higher perception of identity value. In the process of home-return travel, a virtuous circle of diaspora tourism and rural tourism is formed and thus builds a sustainable rural tourism development model.

This study contributes to the theoretical understanding of diaspora nostalgia. It is among the first to qualitatively measure the nostalgia of overseas Chinese and segment them into three clusters based on the five-factor nostalgia measurement scale. By analyzing the differences in involvement and behavior intentions of different groups, this study also provides insight into the relation of nostalgia tourism and national and cultural identity. The current studies on the relationship between tourism and national identity mainly focus on domestic tourism [51,52] or dark tourism in historical sites [53], while this study explores their relationship in the international tourism context.

The findings of this study also provide several practical implications. First, China is currently striving to realize rural revitalization, and many rural areas are encouraged to develop rural tourism and change into tourist destinations. Rural tourism is an important carrier of sustainable rural development. The sustainable development of rural areas is the result of multidimensional effects. While specifying relevant rural revitalization policies, it is necessary to pay attention to the characteristics of the rural tourist source market and carry out corresponding promotion activities in a targeted manner. Overseas Chinese are an important source of inbound tourists. The Chinese tourism authorities should be more active in marketing the country to the Chinese diaspora to create a new brand identity. Destination designers can adopt customized advertisements with old songs, scenes of old places, old settings, traditional festivals, cultural activities, and other methods that create a nostalgic atmosphere to stimulate nostalgia, especially with stories and videos about 
cultural activities to enhance the group identity. Promoting homeland and developing nostalgia tourism is conducive to building a mutually beneficial and win-win relationship between overseas Chinese and local villages and exploring new paths for sustainable rural development in the context of urbanization. Attracting diasporic tourists to participate in home-return travel and rural revitalization is an important force for the sustainable development of the homeland of overseas Chinese.

Second, this study also provides practical implications for homeland construction. The specific feature of homeland not only reflects the inherent characteristics of the local environment and culture but also reflects people's psychological and emotional adaptation to a specific environment, thus forming a local identity and attachment. Memories of homeland experience and homeland environment and identity as overseas Chinese are important sources of nostalgia. Therefore, to "retain nostalgia", it is urgent to protect the cultural environment and historical context of the homeland. Home-return travel is an important carrier for preserving homeland memories, inheriting regional culture and remembering nostalgia. In the process of developing tourism, the stakeholders should take into consideration the ecological culture, material culture, institutional culture, behavioral culture, and spiritual culture of the place to extract cultural genes, determine the connotation of tourism culture reconstruction, and promote the integration and symbiosis of urban (rural) culture and tourism. The living environment will inevitably undergo certain changes, but the cultural landscape genes of the homeland must be effectively protected and inherited. Only in this way can people's psychological needs for homeland memory and sense of place be met.

Author Contributions: Conceptualization, Y.Z. and R.X.; methodology, Y.Z.; software, R.X.; validation, R.X.; formal analysis, Y.Z.; investigation, Y.Z. and R.X.; resources, Y.Z.; data curation, Y.Z.; writing —original draft preparation, Y.Z.; writing—review and editing, Y.Z.; visualization, R.X.; supervision, R.X.; funding acquisition, Y.Z. and R.X. All authors have read and agreed to the published version of the manuscript.

Funding: This research was funded by Fujian Provincial Innovation Strategy Research Project (Grant No. 2021R0048), the National Natural Science Foundation of China (Grant No. 41971261), the Natural Science Foundation of Fujian province of China (Grant No. 2019J01430), the China Mindong Tourism Poverty Alleviation Research Center, 2020 Open Project (Grant No. EFTPARC202001), and the Scientific Research and Development Foundation of Fujian University of Technology (Grant No. GY-Z18181).

Institutional Review Board Statement: The study was conducted according to the guidelines of the Declaration of Helsinki, and approved by the Institutional Review Board of College of Tourism, Fujian Normal University (protocol code 2020121; date of approval: 10 December 2020).

Informed Consent Statement: Informed consent was obtained from all subjects involved in the study.

Data Availability Statement: The data presented in this study are available on request from the corresponding author. The data are not publicly available because this study signed a confidentiality pledge with the respondents.

Acknowledgments: The authors would like to thank the anonymous reviewers and editors for their helpful suggestions for the improvement of this paper.

Conflicts of Interest: The authors declare no conflict of interest.

\section{References}

1. Wang, H.; Miao, L. Annual Report on Chinese International Migration; Social Science Academic Press: Beijing, China, 2020.

2. Overton, J. Coming Home: Nostalgia and Tourism in Newfoundland. Acadiensis 1984, 14, 84-97.

3. Huang, W.J.; Ramshaw, G.; Norman, W.C. Homecoming or tourism? Diaspora tourism experience of second-generation immigrants. Tour. Geogr. 2016, 18, 59-79. [CrossRef]

4. Timothy, D.J.; Coles, T. Tourism and diasporas: Current issues and future opportunities. In Tourism, Diasporas and Space; Coles, T., Timothy, D., Eds.; Routledge: London, UK, 2004; pp. 291-297.

5. Davis, F. Yearning for Yesterday: A Sociology of Nostalgia; Free Press: New York, NY, USA, 1979; pp. 95-102.

6. Cohen, E. Authenticity and commoditization in tourism. Ann. Tour. Res. 1988, 15, 371-386. [CrossRef] 
7. Dann, G.M.S. Tourism and nostalgia: Looking forward to going back. Vrijetid En Samenlev. 1994, 12, 75-94.

8. Dann, G.M.S. Nostalgia in the noughties. In Global Tourism; Theobald, W., Ed.; Butterworth-Heinemann: Burlington, MA, USA, 2005; pp. 33-50.

9. Graburn, N.H.H. Tourism, modernity and nostalgia. In The Future of Anthropology: Its Relevance to the Contemporary World; Ahmed, A., Shore, C., Eds.; Athlone Press: London, UK, 1995; pp. 158-178.

10. MacCannell, D. Staged authenticity: Arrangements of social space in tourist settings. Am. J. Sociol. 1973, 79, 589-603. [CrossRef]

11. Peleggi, M. Consuming colonial nostalgia: The monumentalisation of historic hotels in urban South-East Asia. Asia Pac. Viewp. 2005, 46, 255-265. [CrossRef]

12. Urry, J. How societies remember the past. In Theorizing Museums: Representing Identity and Diversity in a Changing World; Macdonald, S., Fyfe, G., Eds.; Blackwell Publishers: London, UK, 1996; pp. 45-68.

13. Kim, S.; Kim, S.; Petrick, J.F. The effect of film nostalgia on involvement, familiarity, and behavioral intentions. J. Travel Res. 2019, 58, 283-297. [CrossRef]

14. Bandyopadhyay, R. Nostalgia, Identity and Tourism: Bollywood in the Indian Diaspora. J. Tour. Cult. Chang. 2008, 6, 79-100. [CrossRef]

15. Marschall, S. "Personal memory tourism" and a wider exploration of the tourism-memory nexus. J. Tour. Cult. Chang. 2012, 10, 321-335. [CrossRef]

16. Suntikul, W. Nostalgia-motivated Thai domestic tourism at Amphawa, Thailand. Asia Pac. J. Tour. Res. 2017, 22, 1038-1048. [CrossRef]

17. Cho, H.; Ramshaw, G.; Norman, W.C. A conceptual model for nostalgia in the context of sport tourism: Re-classifying the sporting past. J. Sport Tour. 2014, 19, 145-167. [CrossRef]

18. Cho, H.; Khoo, E.C.; Lee, H.W. Nostalgia, motivation, and intention for international football stadium tourism. Asia Pac. J. Tour. Res. 2019, 24, 912-923. [CrossRef]

19. Li, T.L.; McKercher, B. Effects of place attachment on home return travel: A spatial perspective. Tour. Geogr. 2016, 18, 359-376. [CrossRef]

20. Li, T.E.; Chan, E.T.H. Diaspora tourism and well-being: A eudaimonic view. Ann. Tour. Res. 2017, 63, 205-206. [CrossRef]

21. Stern, B.B. Historical and personal nostalgia in advertising text: The fin de siècle effect. J. Advert. 1992, 21, 11-22. [CrossRef]

22. Liu, P.L. The theory and practice exploration of "remembering nostalgia" in the construction of new urbanization. Geogr. Res. 2015, 34, 1205-1212.

23. Lu, S.M. Temporal and spatial image of Chinese xiangchou and its urban humanistic renaissance. Mod. Urban Res. 2016, 8, 2-10.

24. Huang, Z.F.; Lu, L.; Su, Q.; Zhang, J.; Sun, J.; Wan, X.; Jin, C. Research and development of rural tourism under the background of new urbanization: Theoretical reflection and breakthrough of predicament. Geogr. Res. 2015, 34, 1409-1421.

25. Wang, X.G.; Tian, C.; Lin, M.S.; Wang, S.K. Review of nostalgia research. Hum. Geogr. 2018, 33, 1-11.

26. Chen, H.B.; Yeh, S.S.; Huan, T.C. Nostalgic emotion, experiential value, brand image, and consumption intentions of customers of nostalgic-themed restaurants. J. Bus. Res. 2014, 67, 354-360. [CrossRef]

27. Leong, A.M.W.; Yeh, S.S.; Hsiao, Y.C.; Huan, T.C. Nostalgia as travel motivation and its impact on tourists' loyalty. J. Bus. Res. 2015, 68, 81-86. [CrossRef]

28. Meng, Z.; Cai, L.; Day, J.A.; Tang, C.H.; Lu, Y.; Zhang, H. Authenticity and nostalgia—subjective wellbeing of Chinese rural-urban migrants. J. Herit. Tour. 2019, 14, 506-524. [CrossRef]

29. Gao, J.; Lin, S.; Zhang, C. Authenticity, involvement, and nostalgia: Understanding visitor satisfaction with an adaptive reuse heritage site in urban China. J. Destin. Mark. Manag. 2020, 15, 1-10. [CrossRef]

30. Lee, Y.-J. Creating memorable experiences in a reuse heritage site. Ann. Tour. Res. 2015, 55, 155-170. [CrossRef]

31. Cho, H. How nostalgia forges place attachment and revisit intention: A moderated mediation model. Mark. Intell. Plan. 2021, 39, 856-870. [CrossRef]

32. Hughes, H.; Allen, D. Holidays of the Irish diaspora: The pull of the 'homeland'? Curr. Issues Tour. 2010, 13, 1-19. [CrossRef]

33. Murdy, S.; Alexander, M.; Bryce, D. What pulls ancestral tourists 'home'? An analysis of ancestral tourist motivations. Tour. Manag. 2018, 64, 13-19. [CrossRef]

34. Huang, W.J.; Hung, K.; Chen, C.C. Attachment to the home country or hometown? Examining diaspora tourism across migrant generations. Tour. Manag. 2018, 68, 52-65. [CrossRef]

35. Li, T.E.; Chan, E.T.H. Connotations of ancestral home: An exploration of place attachment by multiple generations of Chinese diaspora. Popul. Space Place 2018, 24, e2147. [CrossRef]

36. Li, T.E.; Chan, E.T.H. Diaspora tourism and well-being over life-courses. Ann. Tour. Res. 2020, 82, 1-12. [CrossRef]

37. Campos, A.C.; Mendes, J.; Valle, P.O.; Scott, N. Co-creating animal-based tourist experiences: Attention, involvement and memorability. Tour. Manag. 2017, 63, 100-114. [CrossRef]

38. Josiam, B.M.; Smeaton, G.; Clements, C.J. Involvement: Travel motivation and destination selection. J. Vacat. Mark. 1999, 5, 167-175. [CrossRef]

39. Prebensen, N.K.; Woo, E.; Chen, J.S.; Uysal, M. Motivation and involvement as antecedents of the perceived value of the destination experience. J. Travel Res. 2012, 52, 253-264. [CrossRef]

40. Gursoy, D.; Gavcar, E. International leisure tourists' involvement profile. Ann. Tour. Res. 2003, 30, 906-926. [CrossRef]

41. Laurent, G.; Kapferer, J. Measuring Consumer Involvement Profiles. J. Mark. Res. 1985, 22, 41-53. [CrossRef] 
42. Kyle, G.; Chick, G. Enduring Leisure Involvement: The Importance of Relationships. Leis. Stud. 2004, 23, 243-266. [CrossRef]

43. Clements, J.; Josiam, B. Role of Involvement in the Travel Decision. J. Vacat. Mark. 1995, 1, 337-348. [CrossRef]

44. Lee, J.; Beeler, C. An Investigation of Predictors of Satisfaction and Future Intention: Links to Motivation, Involvement, and Service Quality in a Local Festival. Event Manag. 2009, 13, 17-29. [CrossRef]

45. Kim, S.; Scott, D.; Crompton, J.L. An Exploration of the Relationships among Social Psychological Involvement, Behavioral Involvement, Commitment, and Future Intentions in the Context of Birdwatching. J. Leis. Res. 1997, 29, 320-341. [CrossRef]

46. Havitz, M.E.; Dimanche, F. Propositions for testing the involvement construct in recreational and tourism contexts. Leis. Sci. 1990, 12, 179-195. [CrossRef]

47. McIntyre, N. The Personal Meaning of Participation: Enduring Involvement. J. Leis. Res. 1989, 21, 361-370. [CrossRef]

48. Cho, H.; Lee, H.W.; Moore, D.; Norman, W.C.; Ramshaw, G. A multilevel approach to scale development in sport tourist nostalgia. J. Travel Res. 2017, 56, 1094-1106. [CrossRef]

49. Cho, H.; Pyun, D.Y.; Wang, C.K. Leisure nostalgia: Scale development and validation. J. Leis. Res. 2019, 50, 330-349. [CrossRef]

50. Lazarus, R.S. Cognition and motivation in emotion. Am. Psychol. 1991, 46, 352-367. [CrossRef] [PubMed]

51. Holak, S.L.; Matveev, A.V.; Havlena, W.J. Nostalgia in post-socialist Russia: Exploring applications to advertising strategy. J. Bus. Res. 2007, 60, 649-655. [CrossRef]

52. Liu, R.; Huang, Z.; Yu, R.; Bao, J.; Mo, Y. The impact of red tourism on national identity of tourists. J. Nat. Resour. 2021, 36, 1673-1683. [CrossRef]

53. Packer, J.; Ballantyne, R.; Uzzell, D. Interpreting war heritage: Impacts of Anzac Museum and battlefield visits on Australians' understanding of national identity. Ann. Tour. Res. 2019, 76, 105-116. [CrossRef] 